倍量の水に注ぎたる後炭酸ソーダ溶液尼以て中和す・かーロダンアニリンは無色結

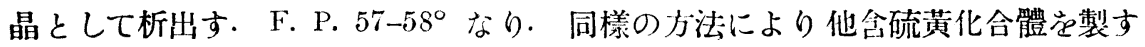
ることな得. かーロダンアセトンアニリド $\left(\mathrm{C}_{9} \mathrm{H}_{8} \mathrm{ON} \mathrm{N}_{2} \mathrm{~S}\right)$, F. P. 188 . ヂアセチルア そノーエトオキシーベンツチアツォル, F, P. $245^{\circ} . \quad フ_{ォ}$ ルルーかーロダンフェニルヒ ドラチン, F.P. 1:32。.アセチルロダンフェニルヒドラチン, F.P. 171 . ベンツォ イルロダンフェニルヒドラチン, F. P. 164。. 殺菌劑とまた同樣の方法により得ら る。郎ち原料としては一オキシノリンを用ひオキシロダンヒ, リンを製す。また 同樣にしてロダンクレデール虎得らる.

（王蟲）

\title{
V. 贜器藥品化學
}

睟臟ホルモン製法 Gedeon Richter： Ung. P. 103352（1931）膵臟に蛋白 質丈は類似物質を沈澱せしむべき沒食子酸, スルフォサリチル酸, タンニンの如き 有機酸或は其溶液觉混じ酒精, 木精プロピルアルコホルの如き水と混和すべき溶 劑で抽出し沈澱と分離すると沈澱から穊知の方法によつで Trypsin を製すること を得溶液からホルモン进得. (C. (1922) I. 3203)

(緒力j)

腦下垂體生長ホルモン Alex. Simon u. L. Binder: Aepp 165 (1932) 120 著者は 5 種の市販製品觉試驗したが其內ただ一が弱き作用を持ていたのみであ る. 檢定方法としては Van Dyke u. Wallen-Lawrence 法は最適である. 雌白鼠 は雄よりも容易に反應する.Thymocrescin は Phyon の特種な生長曲線定有しな い. (C. (1932) I. 3192)

(緒方)

腦下垂體中葉ホルモンの硡究 (II) Zondek und Krohn: Kilin. Woch. 20 849 (1932) Zondek 等は前報に於て（本誌 489 頁 (1932) 抄錄) 腦下垂體中葉 ホルモンとして Intermedin を得, 其の Erythoropho:en 反應范荻見し目吱位P.E. を定めたり."原料たる屠殺直後の牛の腦下垂體は鈆利なる小刀尚以て殆ぞ中葉の

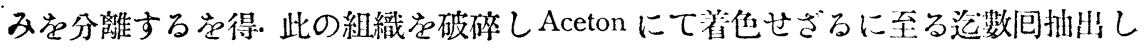

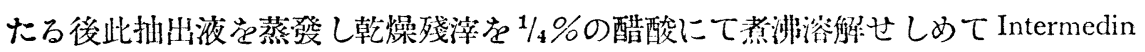
を得たり. 份腦下垂體各部に就きてホルモン量を测定したる絬果は前葉（1gに 付 $2857 \mathrm{PE}$ ) 中葉 (1g に付 $80000 \mathrm{PE}$ ) 後葉 (1g に付 $11904 \mathrm{PE}$ ) にして中葉最 も多く更に詳練なる研究絬果によれば前後葉共に中葉に近接せる部に特に多し 是 Intermedinは擴散に㩝りて 前葉の腺狀部位站に後葉の析經細胞胸部に混じた るものと見做すを得. かくして中葉ホルモンとしての Intermedin 丞確證せり. 動物に於ける腅下垂體の Intermedin 量は Phoxinus laevis (7 P.E.) 蛙 (10 P.E.) 鷄 (75 P.E.) 家鬼 (2-300 P.E.) 等 (2500 P. E.) 猿 (1000 P. E.) 人間成人 (47000 P. E.) 同新生兒 (60 P. E.). 更に数種の狱人中琵小は惡性径血 (1400 P. E.) 
にして最富は尿毒定 (10000 P. E.) 肝臟癌 (12000 P. E.) 生殖器性肥肪肥大 $(13000$ I.E.) なりとす。份第 3 腦空壁に僅かの Intermedin を證明したる外腦部以外の

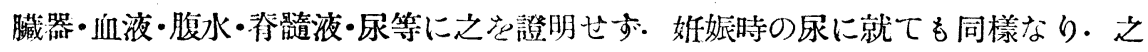
より推察すれば Intermedin は中葉にて生產せられ, 第 3 腦宝にて完全に消費せら るらちのの如し.

(緒方)

性ホルモンの化學 A. Butenandt：Ch。Zt. 483 (1932) 性ホルモンはえ㾟 分ちて 2 となし得べし. 1. Follikelhormon (E.A. Doisy. A. Butenaudt) 2. Testikelhormon. (A. Butena .dt, K. Tehernig) これなり.

1. Follikelhormon. 著者は之を分ちて動物界に於ける女性ホルモン及植物界 に於ける Blühhormon とせり. 主要なるものに $\alpha$-Follikelhormon $\mathrm{C}_{18} \mathrm{H}_{22} \mathrm{O}_{2}$ 及 Follikelhormonhydrat $\mathrm{C}_{1 \mathrm{~s}} \mathrm{H}_{24} \mathrm{O}_{3}$ あり. 前者は Oxyketon にして後者は Triol なり. 兩者共酸性水酸基 1 储右有す. 研究の結果 Follikelhormon は 3 個のベンジール 2 重結合品有し, 且 4 偑の環を有す (ベンゾール環 1 偑, 飽和環 3 個). 酸性水酸 基はベンゾール環に，カルボニル基は飽和環に結合す．水酸基とカルボニル基は 分子の兩端に結合す. ホルモン党構成する環に關しては, 亞鉛末による Dehydricrung によりて放否族炭化水素 $\mathrm{C}_{18} \mathrm{H}_{14}$ の製造に成功せり. 即ち(I)の如きるの ならん. Hormon 及 Hormonhydrat は夫ヶ (II) (III) の如きものならん.

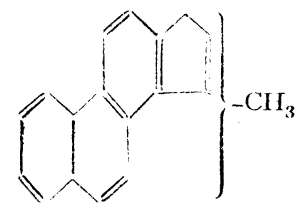

(I)

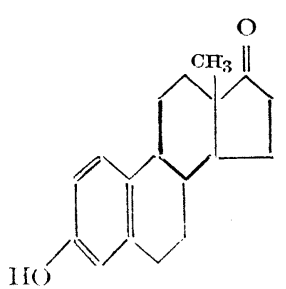

(II)<smiles>CC1CCC2C3CCc4cc(O)ccc4C(CC3O)C12C</smiles>

(III)

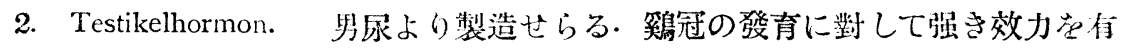
す. Oxyketon なるも飽和性灰后し從つて酸性なし. $\mathrm{C}_{19} \mathrm{H}_{30} \mathrm{O}_{2}$ の如く思はるるも

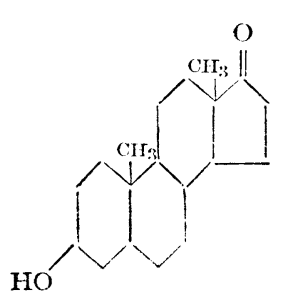

(IV)

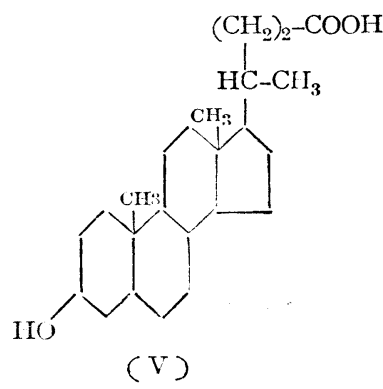

(V)

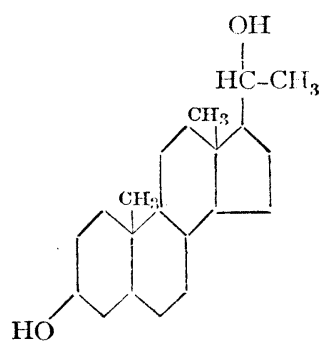

(VI) 
$\mathrm{C}_{18} \mathrm{H}_{28} \mathrm{O}_{2}$ を否定する論據なし. 4 個の環を有し然も悉く飽和性なり. (IV)の如き ものならん。

茲に豫想したる式に從へば兩ホルモンは Sterin 及 Gallensäure (V) (Rosenheim, King, Wieland による）に近き關係を有し，郎ちその酸化成績體ならん，之等の推 定は確賽なるものならん. 何となれば之等の分解の中間成績體が Hormon の透伴

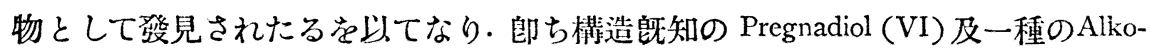
hol $\mathrm{C}_{19} \mathrm{H}_{32} \mathrm{O}_{2}$ (VII?)之なり.

(刘米)<smiles>CC1(O)CCC2C3CCC4CC(O)CCC4C3CCC21C</smiles>

(VII)

Auxin の化罗 F. Kögl: Ch. Zt 783 (1932) Auxin 製造の最良原料は人 尿にして之より分離したるAuxin は融點 $195^{\circ}$ の結晶にして水溶液は弱左旋性

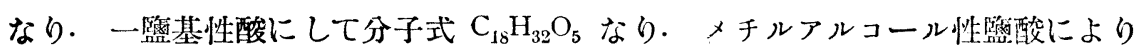
て中性の Auxin-lacton $\mathrm{C}_{18} \mathrm{H}_{30} \mathrm{O}_{4}$ を生す，カルボキシル基 1 個, 水酸基 3 㐿, 二重結 合 1 個, 炭素環 1 個を有す。光を遮りて真空中に眝藏すれば $1 \sim 2$ ケ月间其效力 を完全に保持し得. 研究の結果に依れば各人(年齡,性，の如何觉間はず)の尿中に

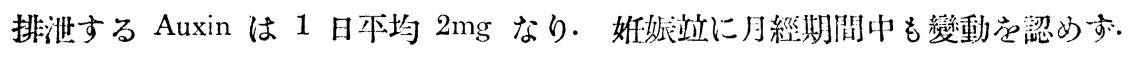
Auxin の大部分は食事攝取後短時間に排泄さる.（本誌1032 頁參照）（刈米）

\section{IV. 藥品製造學}

\section{2-メチル-4-グリコリルアミノベンツァールアルジン酸の製法Ｉ. G.}

Farbenindustrie Akt.-Ges., Frankfurt a. M. 瑞西特許 146786 號 本法は獨逸特許 510451 號; C.(1931) I. 1517 の追加にして次の如し：2-ニトロー5ートルイヂンとグ

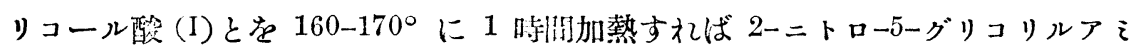
ノトルオールを得,之をアルコール中にて水素とニッタルに還元す礼ば5ーグリコ リルアミンー2ートリイヂンとなる・之はヂァツォ化窟經, 亞砒酸ソーダを作用せしむ れば 2-メチル-4-グリコリルアミバンツォールアルジン酸となり 1 モルの水を 含で結晶し、溫メチルアルコール,アルコール, 醋酸に可㴧性にして融點 195-1970

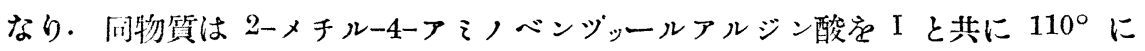
加熱してる得らる. 